\title{
The Effect of Green Strategy and Green Investment Toward Carbon Emission Disclosure
}

\author{
Zalida Afni ${ }^{1}$, Lindawati Gani ${ }^{2}$, Chaerul D Djakman ${ }^{3}$, Elvia Sauki ${ }^{4}$ \\ Politeknik Negeri Padang, Padang, Indonesia ${ }^{1}$ \\ Politeknik Negeri Padang, Padang, Indonesia ${ }^{2}$ \\ Politeknik Negeri Padang, Padang, Indonesia ${ }^{3}$
}

\begin{abstract}
This research aims to test the influence of the green strategy and green investment against disclosure of carbon emissions. Global warming leads to extreme climate change in various places around the world including in Indonesia. There is strong evidence that it is caused by human activity, mainly from burning fossil fuels so as to have an impact on the increasing greenhouse gases. One of the company's efforts in reducing the impact of carbon emissions is by disclosure of carbon emissions. Research on the relationship of the disclosure of carbon emissions by a factor of green strategy and green investments at private sector organization is still relatively limited and there are differences in the methods used. This research contributes to providing empirical evidence about the influence of the green strategy and green investment against disclosure of carbon emissions. Research on the relationship of the disclosure of carbon emissions by a factor of green strategy and green investments at private sector organization is still relatively limited and there are differences in the methods used. This research contributes to providing empirical evidence about the influence of the green strategy and green investment against disclosure of carbon emissions. This research using a sample of companies listed on stock exchanges in the country which is included in the rate of carbon emissions in the world, namely Indonesia and German. This study uses data from the 20142016 period in the annual report and the corporate sustainability report. The results showed that there is a significant influence of the green strategy and green investment against disclosure of carbon emissions
\end{abstract}

Keyword. green strategy; green investment; carbon emission disclosure

Article history. Received Agustus, 2018. Revised Oktober, 2018.Accepted December, 2018

Corresponding author. Email: zalida.afni@yahoo.com

How to cite article. Afni, Z., Gani, L., Djakman, C. D., \& Sauki, E. (2018). The Effect of Green Strategy and Green Investment Toward Carbon Emission Disclosure. The International Journal of Business Review (The Jobs Review), 1(2), 93-108.

https://doi.org/https://doi.org/10.17509/tjr.v1i2.13879

\section{INTRODUCTION}

The increase in the temperature of the surface of the Earth, get significant attention as the issue of global warming, which climate change at various places in the world. Global warming is recognized as a problem that has a high priority throughout the world and the impact of global warming is getting worse (Borghei, Leung, \& Guthrie, 2016; Luo, Tang, \& Lan, 2013). Global warming caused by the activity of the humans and there is powerful new evidence that most of the observed global warming over the last 50 years due to human activities and 90\% comes from fossil fuel combustion (IPCC, 2007). The economic development sector and industrial sector that are getting faster, which effect on climate change and the environment, encouraging the UN made efforts address the impacts of climate change by developing the concept of sustainable development aimed at Global. The effort began in the years 1972 through an environmental conference in Stockholm, Sweden. Then proceed with Our Common Future in Nairobi of the year 1982, the Earth Summit in 
Rio De Janiero years 1992 on the issue of climate change, the Kyoto Protocol on climate change 1997 and the year 2000 birth of the global goal of the MDGs (Millennium Development Goals) 2000-2015. Conference in Johannesburg South Africa and 2002 in Rio De Jainero 2012, developed into a global goal SDGs (Sustainable Development Goals) 20152030 replace the MDGs. One purpose of SDG's is to take urgent action to combat the effects of climate change, and this deal is contained in the Paris Agreement is an international commitment in conducting mitigation efforts by way of reduction of greenhouse gas emissions to reach temperatures below $2 \mathrm{c}$. World Bank data show for the year 2013 total world CO2 emissions amounted to 318 million metric tons. Years of the 1990 's, about twothirds of $\mathrm{CO} 2$ emissions come from developed countries. But this time, the developing countries also experienced a considerable increase in emissions. The top 10 countries the biggest contributors to carbon emissions are China, the U.S., the European Union (28 countries), India, Russia, Indonesia, Brazil, Japan, Canada, and Germany.

Carbon emissions mitigation efforts have been undertaken both at the country level as well as at the level of the company. At the country level, mitigation efforts made through the existence of regulations related to carbon emissions such as EU-UTS European Union Emissions Trading Scheme, including Indonesia and with the commitment to ratify the Kyoto Protocol with law No. 17/2004. However, after the enactment of ACT No. 17/2004 of Indonesia, only about $10 \%$ of manufacturing companies in Indonesia who have committed actions that are associated with the reduction of carbon emissions (Lindrianasari., 2014). At the corporate level, the impact of climate change mitigation efforts can be done by way of disclosure of carbon emissions. More and more scientific evidence suggests that carbon emissions are the main cause of global warming is a serious threat against the lives of both economically, socially and environmentally (Borghei et al., 2016; K. Li \& Lin, 2016; Liao, Luo, \& Tang, 2015; Luo Tang \& 2014a; Luo et al., 2013). Carbon emissions disclosure largely not yet mandatory disclosure is in most of the countries in the world. However many companies prepare the disclosure of carbon emissions on a voluntary basis. This is done to avoid the risk of the company the existence of regulations on climate change in the future and a negative impact on the company's operations (Luo, Lan, Tang \&, 2012).

Reporting or disclosure of carbon emissions through the company's annual report is one of the prevention efforts in carbon emissions that can be performed by the company. Previous research on disclosure of carbon emissions using the CDP questionnaire guide/Carbon Disclosure Project with the measurement does the company disclose or not ((Liao et al., 2015; Luo et al., 2012; Luo Tang \& 2014a 2014b,; Luo et al., 2013; Matsumura, Prakash, \& Vera-Munoz, 2014; Tang \& Luo, 2011). Other research develops components disclosure of carbon emissions based on the 2006 GRI-G3 (Borghei et al., 2016; Y. Li, Eddie, $\& \mathrm{Liu}, 2014)$. Earlier research had yet to develop the components of the complete disclosure of carbon emissions, so it is not yet knowing the level of disclosure made by the company. Therefore this component develops the research disclosure of carbon emissions based on the CDP Guidelines and adapted to the G4-GRI and GHG Protocol.

Previous research identified a green strategy consists of hold-ups, step-up, and frontier (Hansen \& Klewitz, 2012). Other studies adopting green strategy consists of three types, namely the prevention of pollution, products, services and clean technology (Masoumik, Abdul-Rashid, \& Olugu, 2015). Research Duarte \& Machado (2013) identifies the green strategy over lean \& green. There have been no previous studies that tested the levels of green strategy firm based on the type of lean, defensive, shaded, and extreme green strategy (Ginsberg \& Bloom, 2004). This grouping is required to find out if the companies take advantage of opportunities in the face of climate change's effect on the company's ability to manage emissions, expressed in the information disclosure of carbon emissions. Based on 
the description above, this research to formulate the first problem: how to influence the level of green strategy against disclosure of corporate carbon emissions?

According to the International Monetary Fund (IMF), green investment is an investment that is required in adapting to climate change by reducing greenhouse gas emissions without reducing the production and consumption of non-energy significantly. Previous research gives an overview of energy efficiency to use green investment schemes on a case study of the housing sector accounts for $30 \%$ of carbon emissions. These studies provide evidence that investment green became a major force in the energy sector (Czako, 2012). However, it is still a little bit of research to provide evidence of the influence of the green investment towards adaptation to climate change to reduce greenhouse gas emissions through disclosure of carbon emissions. Previous research has yet to provide empirical evidence that tests the influence of green investment company against the disclosure of carbon emissions. Indonesia since the year 2004 has committed with the Act of the Republic of Indonesia No. 3 set about the green industry, but since the 2010-2014 the number of green investments reached $30 \%$ of the total investment. The year 2015 and then Indonesia is hosting Green Investment Conference international level with the theme of the tropical landscape: a global summit investment opportunity and are committed to improving the green investments of $20 \%$ per year. Based on the description above, this research to formulate the second problem: how to influence green investment against disclosure of carbon emissions.

This research aims to analyze the factors that affect the disclosure of carbon emissions that is green and green investment strategy. This research is expected to deliver benefits for the development of science, the Government as the regulator, and industry peers. For science is expected this research can add to the literature on disclosure of carbon emissions the firm views of the factors which affected green strategy and green investment. The study is also expected to contribute by providing empirical evidence of the existence of the influence of the green strategy and green investment against the disclosure of the company's carbon emissions.

\section{THEORETICAL BACKGROUND AND HYPOTHESIS DEVELOPMENT}

\section{Stakeholder Theory}

Stakeholder theory is a theory that gives an overview of the presence of the parties with regard to the interests of the company. Stakeholder groups or individuals who may be affected by the purpose of the company. Stakeholders are defined as those who have involvement in the company either by individuals, groups or organizations. The main stakeholders include employees, managers, shareholders, customers, and suppliers (Phillips, Freeman, \& Wicks, 2003). Stakeholders include groups or individuals include shareholders, creditors, Governments, employees, community and social environment, and the other (Chairiri \& Ghozali, 2007). On the point of view of the theory of stakeholder, the company not only is an economic entity only run operations for its own interests but should provide benefits for the parties the company responsible for their the stakeholders of the company. The company should be able to maintain good relations with stakeholders by understanding the desires of stakeholders, especially stakeholders that have an impact on the availability of the resources used for the operational activity of the company, such as employees, the company's top customers and others (Ghozali \& Chairiri, 2007). Stakeholder theory also requires managers to be able to manage the expectations of the stakeholders and the value that they create and requires managers to understand what is wanted and what is created so that it corresponds to what is expected by stakeholders (Freedman \& Jaggi, 2005). 


\section{Legitimacy Theory}

Theory of legitimacy this provides an explanation of the social responsibility must be disclosed in order that the company gets the legitimacy of the social environment on the spot activities the company operates, and this will give the company financial strength the maximum for a long period of time. Theory of legitimacy is based there is the existence of a social contract between the company with the Community hosts a company running his business and use of economic resources. Legitimacy is a dynamic concept that changes in time and place (Ghozali \& Chairiri, 2007). The company should be able to see between company goals with what became the hope of society against the company. If this is not the note will appear between the legitimacy gap expectations and how to behave and act in the organization. For it, organizations need to adopt a strategy to eliminate these disparities and change public perception through environmental and social disclosure of information (Gray, Kouhy, \& Lavers, 1995). The legitimacy associated with the limitations of the company's values and norms in the conduct of business and is a strategic effort in the development of the company for the long term. The legitimacy of the community will encourage the sustainability of the company for the long term, but if the company cannot adapt to the prevailing norms and values in society, can threaten the very existence of sustainability the company in the future (Deegan \& Soltys, 2007)

\section{Institutional Theory}

Initially, institutional theory focuses on how to explain the structure of the institution in the process affect organizations and behaviors that can be accepted as norms in the Organization (Tolbert \& Zucker, 1996; Scott, 2001) in (Greenwood \& Suddaby, 2006). Institutional theory or the theory of institutional formation that the Organization essentially because of the pressure on the environment of the institutions that led to a change in the organization. Changes in the form of ideas and ideas on environmental organizations that form the behavior in language and symbols which explain the existence of the Organization and accepted as norms in the concept of Organization (Donaldson \& Preston, 1995). The Organization was formed because of the institutional environment that exists around the Organization and strength from outside the Organization through a process of mimicry and compliance. Ideas or ideas that influence was institutionalized and accepted as such organizations norms (DiMaggio \& Powell, 1983). A change of institutional isomorphism can be identified into three mechanisms: first, coercive isomorphism that comes from political influence and legitimacy. Second, mimetic isomorphism, that is generated from a standard response to uncertainty. Third, normative isomorphism, associated with the demands of professionalism (DiMaggio \& Powell, 1983). Isomorphism show result of the Coercive pressure of both formal and non-formal given on the Organization so that the organization took or committed some form of adoption against another organization due to pressure other countries, organizations and the public at large. Pressure on the organization can be felt as a force, or as a solicitation to join in a collision.

Mimetic isomorphism, there is uncertainty also provides a strong impetus for organizations to imitation or mimicking other organizations. When the purpose is still ambiguous, while creating an environment of uncertainty, organizations can model themselves on other organizations. Mimesis or model the behavior on other more successful organization is the dramatic response form is from the uncertainty. One of the most dramatic forms of modeling is the modernization of Japan in the late 19th century on the Western prototype is judged a success, and now American companies in Japan for resolve model applying problem productivity and personnel in their company. Companies that adopt modeling or other company innovation, aiming to enhance their legitimacy, at least try to 
improve the working conditions of the company stepped better. Normative isomorphism is a source of organizational changes that are caused due to the demands of professionalism. To achieve success and legitimacy of the Organization's personnel, must have the commitment and can work in a professional, can compromise the internal organization, leadership, clients, regulators, professional organizations.

\section{Green Strategy}

The term green in major business activities is not a new phenomenon, but it has begun since the year 1980 's (Makower, 2009). This activity not only saves the Earth from climate changes due to the increase in the Earth's temperature caused by the greenhouse effect but can also increase the efficiency of business (Ginsberg \& Bloom, 2004). Classification of the green strategy was developed from the green market strategy mix is divided into four parts, namely lean green, defensive green, shaded green, and extreme green. The strategy of lean Green, the appropriate company reduce product cost comparison of concern related to the environment, and there is no trend in producing environmentally friendly products. For example, the Coca-Cola Co., paying attention to the environment by recycling activities and modify packaging, though it is made to expand the market and establish the brand. The defensive strategy of the green is more appropriate to realize it is very important for the company will be an environmentally friendly industry segment but their very nature temporary. For example, a Huge Clothing Retailer Gap Inc., sponsoring activities and environment program on a small scale, if there is pressure from competitors, environmental activists, or regulators. The strategy of the green shaded more long-term oriented business processes environment-friendly, but not as a major factor, but only as a factor supporting the company's business. For example, the Toyota Prius, have products that are eco-friendly because the efficiency against fuel compared to Toyota Motor. The company chose the strategy of extreme green, on business process starting from the input, process, and output of the process is environmentally friendly and has a strong philosophy will concern the environment. For example the company Bodyshop and Honest Tea of Bethesda (Ginsberg \& Bloom, 2004).

\section{Hypothesis Development}

\section{Effect of Green Strategy and Disclosure of Carbon Emissions}

Companies that disclose information whether it's carbon emissions reporting mandatory or voluntary, knowing of the risks and opportunities that may arise in the face of climate change. Companies can integrate the risks and opportunities in corporate strategies that have an impact on the environment. Especially in companies that its business fields related to climate change such as forestry, energy and transportation, agriculture, industry, and waste, which disclose information on carbon emissions. IBM, Ricoh, and Chevron are examples of companies that have implemented a green strategy in their business processes. Companies that want to take advantage of climate change risks and opportunities by integrating it into the green strategy can emulate companies that have been successful implementing it (mimetic isomorphism).

Previous research to build the framework for the measurement of lean and green strategy (Duarte \& Machado, 2013). The business model approach is used as awards, standards, and frameworks, to provide a comprehensive understanding of each model. GRI is one of the standards that govern certain aspects of green business that has been adopted by dozens of big companies as the standard reporting of environmental and social performance of the company by issuing sustainability reports (Sustainability Report) which includes three dimensions, namely environment, social and economic, in addition to other international 
standards such as ISO14001 (Makower, 2009). The issue of sustainability is a systematic and efficient manner that delivers value to the business prospects. The benefits of sustainability help to determine the key factors that affect profits, dividends and stock prices of companies such as reputation brand strength, competitive products, supply chain (Blackburn, 2007).

Based on the explanation above, the disclosure of information is one of the forms of carbon emissions the company's ability to manage emissions, as a form of an effort to manage the risks and opportunities due to climate change. The risks and opportunities that can be integrated into the form of a corporate strategy that is a green strategy. Previous research has not been made on testing a level green strategy that is lean, defensive, shaded, and extreme green based on grouping of Ginsberg \& Bloom (2004) against the disclosure of the company's carbon emissions. Researchers argue that companies that take advantage of opportunities from the impacts of climate change, by utilizing a competitive advantage through the green strategy, will demonstrate the company's ability to manage carbon emissions through information disclosure of carbon emissions. Based on the explanation above, then the first hypothesis in this study are:

$\mathrm{H} 1$ : company adopting green strategy has a positive influence against the disclosure of the company's carbon emissions.

\section{The influence of Green Investment and disclosure of carbon emissions}

Green investment is an investment that is required in adapting to climate change by reducing greenhouse gas emissions without reducing the production and consumption of significantly (Eyraud et. Al. 2011). Green investment can come from investing in the country or from green FDI (Foreign Direct Investment) as a source of private sector financing and transfer of technology between countries. The industry uses raw materials and environmentally friendly technology, which produces no emissions but has added value, with the concept of reducing, reuse, recycle and recovery. Green industry criteria according to the Ministry of industry of Indonesia is a potential investment sectors group driven as the privately run green investment-friendly environment which includes agriculture, forestry, fisheries, concession geothermal power, processing industry, such as biomass, biofuels, an industry manufacturing and low cost green car components (LCGC), procurement of electricity from renewable sources, the procurement of electricity from renewable sources, biogas, and garbage or waste, waste management and recycling, as well as nature tourism.

UU RI No. 3/2014 about the industry (article 77-83) set about the green industry in Indonesia. Expansion of green investment relates to the progress of technology and innovation. This is related to the use of new technologies related to the cost of the R\&D company (Eyraud, Clements, \& Wane, 2013). In the financial sector, concern and responsibility towards the environment have increased investment opportunities in green mutual funds (Climent \& Soriano, 2011; Czako, 2012). Economic growth leads to higher demand against energy resources, which then increases the level of emissions and potentially add to environmental degradation (Ahmed, 2014; Eyraud et al., 2013).

$\mathrm{H} 2$ : Green investment has a positive influence on the disclosure of carbon emissions.

\section{RESEARCH METHOD}

In this study, the population is all of the companies listed on the Indonesia stock exchange and the Frankfurt Stock Exchange. The selection of the sample was based on these countries is producing the world's largest carbon emissions, a commitment to the international accord on emissions mitigation, and the EU is a country that started a pilot initiative in an effort 
mitigation of carbon emissions. The criteria used is the sample of companies listed on the respective stock exchange each country sample, excluding the financial and banking sector, the company that issued the annual report, the Sustainability Report, and the Social Responsible Investment (SRI). The research period is the year 2014-2016. The research framework is as follows:

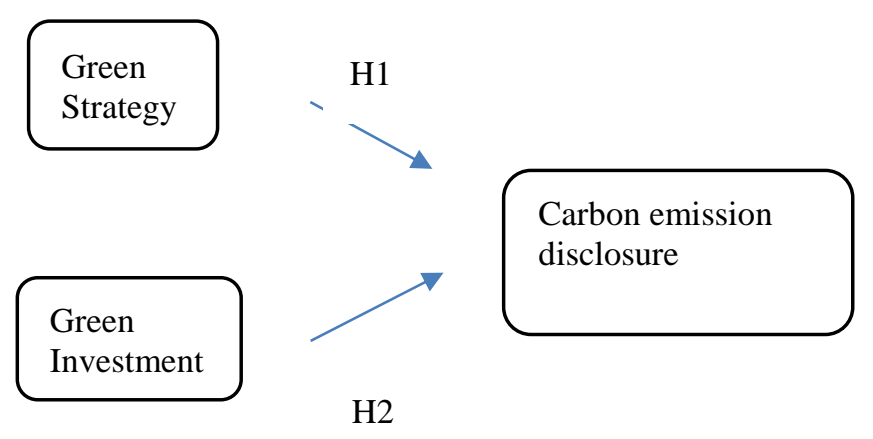

Figure 1: Research Framework

In this research, data processing for green strategy and disclosure of carbon emissions using a content analysis with the help of the NVIVO11 program, and testing these hypotheses using data panel with STATA program. Models used in testing the influence of green strategy and green investment against disclosure of carbon emissions are as follows:

$\mathrm{EM}_{2}$ DISC $\mathrm{it}_{\mathrm{it}}=\alpha_{1}+\alpha_{2} \mathrm{GS}_{\mathrm{it}}+\alpha_{2} \mathrm{GI}_{-} \mathrm{SRI}_{\mathrm{it}}+\alpha_{3} \mathrm{Size}_{\mathrm{it}}+\alpha_{4} \mathrm{IND}_{-} \mathrm{SECkd} \_I n d+\alpha_{5} \mathrm{KD} \_\mathrm{NEG}+\varepsilon_{\mathrm{it}}$

$$
\begin{array}{ll}
\text { EM_DISC } & =\text { Carbon Emission Disclosure } \\
\text { GS } & =\text { Green Strategy } \\
\text { SRI } & =\text { Green Investment }
\end{array}
$$

Table 1. Variable Summary

\begin{tabular}{clcl}
\hline No & \multicolumn{1}{c}{ Variable } & \multicolumn{1}{c}{ Indicator } \\
\hline 1 & $\begin{array}{l}\text { Disclosure of } \\
\text { emission }\end{array}$ & carbon & Content analysis (Annual report) \\
2 & Green Strategy & Content analysis (Sustainability Report) \\
3 & Green Investment & Social Responsible investing Index \\
\hline
\end{tabular}

The proxy used for climate change strategy is the disclosure of carbon emissions (EM_DISC). Disclosure of the Carbon Emission (EM_DISC) is the disclosure of carbon emissions the firm (i) a year (t). Data used in this study are derived from the annual report and sustainability report. Carbon emissions disclosure components developed on the basis of the components of the disclosure that comes from the CDP's 2016 Climate Change 
Information, GRI-G4, and GHG Protocol. Component outline disclosure is retrieved from the CDP's 2016 Climate Change Information that includes three sections; management, risks and opportunities, accounting of emissions, energy use and fuel, the trade component, but the disclosure of the CDP in the form of voluntary questioners, while in this study cannot be questioners. This research complements previous research (Borghei et al., 2016; Choi et al., 2013) using components disclosure of emission reduction targets, indirect emissions coverage, and coverage of other indirect emissions (according to the GHG Protocol).

Table 2. List of Disclosure of Carbon Emission

\begin{tabular}{|c|c|c|c|}
\hline Category & Disclosure items & Max score & Score \\
\hline \multirow[t]{2}{*}{ Introduction } & GHG01 Report Period & 1 & \\
\hline & GHG02 General description of the organization & 1 & \\
\hline \multirow[t]{18}{*}{ Management } & Governance & & \\
\hline & $\begin{array}{l}\text { GHG03 Department/individual/highest level } \\
\text { responsible for climate change }\end{array}$ & 1 & \\
\hline & $\begin{array}{l}\text { GHG04 Incentive for the management of } \\
\text { climate change }\end{array}$ & 1 & \\
\hline & Strategy & & \\
\hline & GHG05 Carbon emission reduction goals & 1 & \\
\hline & GHG06 Emission reduction program/policy & 1 & \\
\hline & $\begin{array}{l}\text { GHG07 Climate change is integrated into } \\
\text { business strategies }\end{array}$ & 1 & \\
\hline & $\begin{array}{l}\text { GHG08 Activities that could either directly or } \\
\text { indirectly influence public policy on } \\
\text { climate change. }\end{array}$ & 1 & \\
\hline & $\begin{array}{l}\text { GHG09 Management plan and strategies to } \\
\text { reduce global warming }\end{array}$ & 1 & \\
\hline & GHG10 GHG certifications & 1 & \\
\hline & Target dan Initiative & & \\
\hline & a GHG11 Emissions reduction target & 1 & \\
\hline & GHG12 Goods/services that low carbon & 1 & \\
\hline & GHG13 Use of new technologies & 1 & \\
\hline & $\begin{array}{l}\text { GHG13 Energy conservation (reductions on } \\
\text { energy consumption) }\end{array}$ & 1 & \\
\hline & GHG14 Use of renewable energy & 1 & \\
\hline & $\begin{array}{l}\text { GHG15 Implementation management } \\
\text { plan/programs }\end{array}$ & 1 & \\
\hline & $\begin{array}{l}\text { GHG16 Employee training/incentive to } \\
\text { activities associated with global } \\
\text { warning }\end{array}$ & 1 & \\
\hline Risk and & GHG17 Identify climate change risk & 1 & \\
\hline \multirow[t]{2}{*}{ Opportunities } & GHG18 Identify climate change opportunities & 1 & \\
\hline & $\begin{array}{l}\text { GHG19 Analysis of business risk and } \\
\text { opportunity caused by climate } \\
\text { change }\end{array}$ & 1 & \\
\hline Metodology, & GHG20 Emission resources & 1 & \\
\hline $\begin{array}{l}\text { Emissions Data, } \\
\text { Enissions }\end{array}$ & $\begin{array}{l}\text { GHG21 Measuring/calculating of carbon } \\
\text { emission }\end{array}$ & 1 & \\
\hline \multirow[t]{5}{*}{ Performance } & GHG22 Total amount of carbon emission & 1 & \\
\hline & GHG23 Carbon emissions limit & 1 & \\
\hline & $\begin{array}{l}\text { GHG24 Organizations documents on carbon } \\
\text { emissions }\end{array}$ & 1 & \\
\hline & $\begin{array}{l}\text { GHG } 25 \text { Scope emission sources more than one } \\
\text { country }\end{array}$ & 1 & \\
\hline & GHG26 Intensity carbon emission & 1 & \\
\hline
\end{tabular}




\begin{tabular}{clcc}
\hline Category & Disclosure items & Max score & Score \\
\hline & GHG27 Emission trading & 1 & \\
& Total & 27 & \\
\hline
\end{tabular}

Companies that disclose information of each item is given a value of 1 (one) and who did not reveal the value of 0 (zero). The total number of items of disclosure of aggregated, divided by the total number of disclosure, in order to obtain the overall score for each company. The higher the index value of the disclosure of a company, means of information disclosure of carbon emissions are higher the company disclosed.

Green Strategy

This research uses the standards of the Global Reporting Initiative GRI/(GRI, 2013). GRI standards used are based on G4 sustainability guidelines that contain common standards and standards of disclosure. Aspects related to sustainable development GRI that contains the three dimensions of sustainability i.e. environmental, social and economic.

Tabel 3. Category ECONOMIC

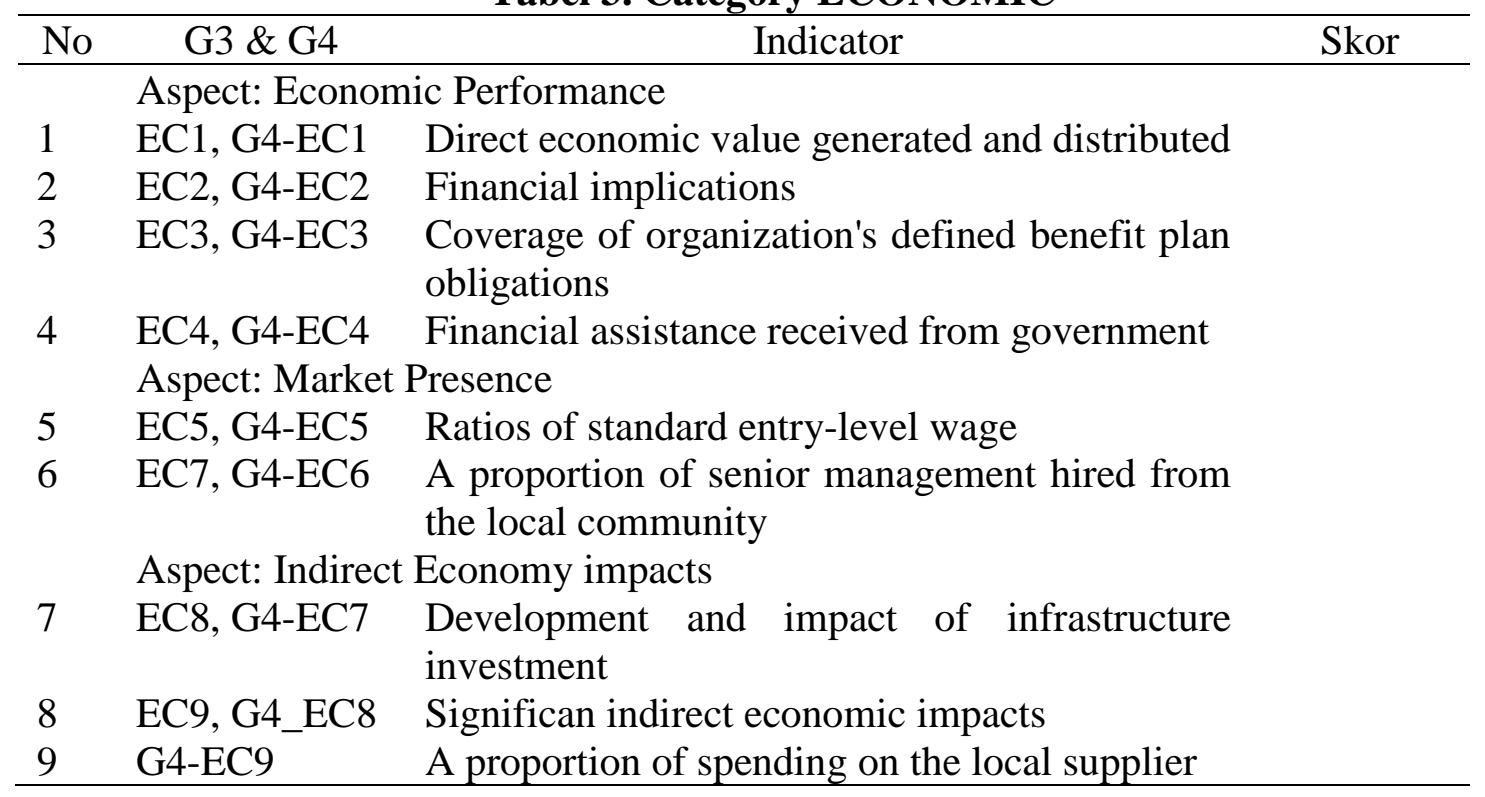

Table 4. Category ENVIRONMENT

\begin{tabular}{|c|c|c|c|}
\hline No & G3 \& G4 & Indicator & Skor \\
\hline & Aspect: Material & & \\
\hline 10 & EN1, G4-EN1 & Materials used by weight or volume & \\
\hline \multirow[t]{2}{*}{11} & EN2, G4-EN2 & $\begin{array}{l}\text { Percentage of materials used that are recycled } \\
\text { input materials }\end{array}$ & \\
\hline & Aspect: Energy & & \\
\hline 12 & EN3, G4-EN3 & Energy consumption within the organization & \\
\hline 13 & EN4, G4-EN4 & Energy consumption outside the organization & \\
\hline 14 & EN5, G4-EN5 & Energy intensity & \\
\hline 15 & EN6, G4-EN6 & Reduction of energy consumption & \\
\hline \multirow[t]{2}{*}{16} & EN7, G4-EN7 & $\begin{array}{l}\text { Reduction in energy requirement of the } \\
\text { product }\end{array}$ & \\
\hline & Aspect: Water & & \\
\hline 17 & EN8, G4-EN8 & Total water withdrawal by source & \\
\hline 18 & EN9, G4-EN9 & $\begin{array}{l}\text { Water source significantly affected by the } \\
\text { withdrawal of water }\end{array}$ & \\
\hline
\end{tabular}




\begin{tabular}{|c|c|c|c|}
\hline \multirow{3}{*}{$\begin{array}{l}\text { No } \\
19\end{array}$} & G3 \& G4 & Indicator & Skor \\
\hline & EN10, G4-EN10 & $\begin{array}{l}\text { Percentage and a total volume of water } \\
\text { recycled and reused }\end{array}$ & \\
\hline & \multicolumn{2}{|c|}{ Aspect: Biodiversity } & \\
\hline 20 & EN11, G4-EN11 & $\begin{array}{l}\text { Operational sited owned, leased, managed in, } \\
\text { or adjacent to, protected areas and areas of high } \\
\text { biodiversity value outside protected areas }\end{array}$ & \\
\hline 21 & EN12, G4-EN12 & $\begin{array}{l}\text { Description of significant impacts of activities } \\
\text { products and services on biodiversity in } \\
\text { protected areas }\end{array}$ & \\
\hline 22 & EN13, G4-EN13 & Habitat protected or restored & \\
\hline \multirow[t]{2}{*}{23} & EN14, G4-EN14 & $\begin{array}{l}\text { Total number of IUCN red list species with } \\
\text { habitat in areas affected by operations, by a } \\
\text { level of extinction risk }\end{array}$ & \\
\hline & \multicolumn{2}{|l|}{ Aspect: Emission } & \\
\hline 24 & EN16, G4-EN15 & Direct GHG Emission scope 1 & \\
\hline 25 & EN17, G4-EN16 & Indirect GHG emission scope 2 & \\
\hline 26 & G4-EN17 & Another GHG emission scope 3 & \\
\hline 27 & G4-EN18 & GHG emission intensity & \\
\hline 28 & EN18, G4-EN19 & Reduction GHG emission & \\
\hline 29 & EN19, G4-EN20 & Emission of ozone-depleting substances & \\
\hline 30 & EN20, G4-EN21 & NOx, Sox, and another significant air emission & \\
\hline 31 & $\begin{array}{l}\text { Aspect: Effects an } \\
\text { EN21, G4-EN22 }\end{array}$ & $\begin{array}{l}\text { d Waste } \\
\text { Total water discharge by quality and } \\
\text { destination }\end{array}$ & \\
\hline 32 & EN22, G4-EN23 & $\begin{array}{l}\text { Total weight of waste by type and disposal } \\
\text { method }\end{array}$ & \\
\hline 33 & EN23, G4-EN24 & Total number and volume of significant spills & \\
\hline 34 & EN24, G4-EN25 & $\begin{array}{l}\text { A weight of transported, imported, or treated } \\
\text { waste deemed hazardous }\end{array}$ & \\
\hline 35 & EN25, G4-EN26 & $\begin{array}{l}\text { Identity, size, protected status and biodiversity } \\
\text { value of water bodies }\end{array}$ & \\
\hline 36 & $\begin{array}{l}\text { Aspect: Product ar } \\
\text { EN26, G4-EN27 }\end{array}$ & $\begin{array}{l}\text { ad Service } \\
\text { the extent of impact mitigation of } \\
\text { environmental impacts of products and } \\
\text { services }\end{array}$ & \\
\hline \multirow[t]{2}{*}{37} & EN27, G4-EN28 & $\begin{array}{l}\text { Percentage of product sold and their packaging } \\
\text { materials that are reclaimed by category }\end{array}$ & \\
\hline & \multicolumn{2}{|c|}{ Aspect: Compliance } & \\
\hline 38 & EN28, G4-EN29 & $\begin{array}{l}\text { The monetary value of significant fines and a } \\
\text { total number of non-monetary sanction for } \\
\text { non-compliance with the environmental law }\end{array}$ & \\
\hline 39 & $\begin{array}{l}\text { Aspect: Transport } \\
\text { EN29, G4-EN30 }\end{array}$ & $\begin{array}{l}\text { Significant of the environmental impact of } \\
\text { transporting product and other goods }\end{array}$ & \\
\hline 40 & $\begin{array}{l}\text { Aspect: Overall } \\
\text { EN30, G4-EN31 } \\
\text { Aspect: Supplier E }\end{array}$ & $\begin{array}{l}\text { Total environment protection expenditures and } \\
\text { investments by type. } \\
\text { Environment assessment }\end{array}$ & \\
\hline
\end{tabular}

102 | The International Journal of Business Review (The Jobs Review) Vol.1 | No.2 | 2018 


\begin{tabular}{llll}
\hline No & G3 \& G4 & \multicolumn{1}{c}{ Indicator } & Skor \\
\hline 41 & G4-EN32 & $\begin{array}{l}\text { Persentase new supplier } \\
\text { Significant actual and potential negative } \\
\text { environmental impact in the supply chain }\end{array}$ & \\
& G4-EN33 & $\begin{array}{l}\text { Aspect : Environment grievance mechanism } \\
\text { Gumber of grievances about environmental } \\
\text { G4-EN34 }\end{array}$ & \\
\hline
\end{tabular}

Table 5. Category SOCIAL

\begin{tabular}{ll}
\hline \multicolumn{1}{c}{ G3 \& G4 } & \multicolumn{1}{c}{ Indicator } \\
\hline Aspect: Employment & $\begin{array}{l}\text { Total number and rate of new employee hires } \\
\text { aAd employee turnover by age group, gender, }\end{array}$ \\
& $\begin{array}{l}\text { and region } \\
\text { A benefit provided to full-time employees } \\
\text { Return to work and retention rates after } \\
\text { parental leave }\end{array}$
\end{tabular}

Aspect: Labor Management

LA4, G4-LA4 Minimum notice period regarding operational changes

Aspect: Occupational health and safety

LA6, G4-LA5 Percentage of total workforce represented in formal joint management

LA7, G4-LA6 Type of injury and rate of injury

G4-LA7 A worker with a high incident or high risk

LA9, G4-LA8 Health and safety topics

Aspect: Training and Education

LA10, G4-LA9 Average hours of training per year per employee by gender

LA11,G4-LA10 Program for skill management

LA12, G4-LA11 Percentage of employees for receiving regular performance and career development

Aspect: Diversity and equal opportunity

LA13, G4-LA12 Composition of governance bodies

Aspect: Equal remuneration for man and woman

LA14, G4-LA13 Ratio of basic salaries and remuneration

Society

Aspect: Local community

SO1, G4-SO1 Percentage of operations with implemented local community engagement

SO9, G4-SO2 Operations with significant actual and potential negative impact on local communities

Aspect: Corruption

$\mathrm{SO} 2, \mathrm{G} 4-\mathrm{SO} 3$ Total number and percentage of operations assessed for risk related to corruption

SO3, G4-SO4 Communication and training for anticorruption

SO4, G4-SO5 Confirm incident of corruption 


\begin{tabular}{|c|c|c|}
\hline G3 \& G4 & Indicator & Skor \\
\hline \multicolumn{3}{|c|}{ Aspect: Public policy } \\
\hline SO5, G4-SO6 & $\begin{array}{l}\text { A total value of political contribution by } \\
\text { country and recipient }\end{array}$ & \\
\hline \multicolumn{3}{|c|}{ Aspect: Anticompetitive } \\
\hline SO7, G4-SO7 & $\begin{array}{l}\text { Total number of legal action for anti- } \\
\text { competitive behavior, antitrust and monopoly }\end{array}$ & \\
\hline \multicolumn{3}{|c|}{ Aspect: Compliance } \\
\hline SO8, G4-SO8 & $\begin{array}{l}\text { The monetary value of significant fines and a } \\
\text { total number of non-monetary sanctions }\end{array}$ & \\
\hline \multicolumn{3}{|c|}{ Aspect : Supplier assessment for impact on society } \\
\hline G4-SO9 & Percentage of a new supplier & \\
\hline G4-SO10 & $\begin{array}{l}\text { Significant actual and potential negative } \\
\text { impact on society in the supply chain }\end{array}$ & \\
\hline \multicolumn{3}{|c|}{ Aspect: Grievance mechanism for impact on society } \\
\hline G4-SO11 & $\begin{array}{l}\text { Number of grievance about the impact on } \\
\text { society filed }\end{array}$ & \\
\hline \multicolumn{3}{|c|}{ Aspect: Product responsibility } \\
\hline PR1, G4-PR1 & $\begin{array}{l}\text { Percentage of significant product and service } \\
\text { categories for which health and safety impact } \\
\text { are assessed for improvement }\end{array}$ & \\
\hline PR2, G4-PR2 & $\begin{array}{l}\text { Total number of incident of non-compliance } \\
\text { with regulation }\end{array}$ & \\
\hline PR3, G4-PR3 & $\begin{array}{l}\text { Type of product and service information } \\
\text { required by the organization procedure }\end{array}$ & \\
\hline PR4, G4-PR4 & $\begin{array}{l}\text { Total number of incident of non-compliance } \\
\text { with regulation }\end{array}$ & \\
\hline PR5, G4-PR5 & $\begin{array}{l}\text { A result of surveys measuring customer } \\
\text { satisfaction }\end{array}$ & \\
\hline PR6, G4-PR6 & Sale of banned or disputed product & \\
\hline PR7, G4-PR7 & $\begin{array}{l}\text { Total number of incident of non-compliance } \\
\text { with regulation }\end{array}$ & \\
\hline PR8, G4-PR8 & $\begin{array}{l}\text { Total number of substantiated complaints } \\
\text { regarding breaches of customer privacy }\end{array}$ & \\
\hline PR9, G4-PR9 & $\begin{array}{l}\text { The monetary value of significant fines for } \\
\text { non-compliance with law and regulation }\end{array}$ & \\
\hline
\end{tabular}

Based on the table above, the indicator used is largely derived from the standard G4-GRI indicators specifically used each having a value of 1 (one) if such information is disclosed in the sustainability report and the value 0 (zero) if such information is not disclosed.

Green Investment

Index of SRI (Sustainable and Responsible Investing or Socially Responsible Investment). SRI is an investment strategy that seeks to consider both financial and social returns. The SRI indices give exposure on the level of the company drawn upon the basis of three categories of fundamental aspects of requirements environmental, social and governance (ESG) in accordance with the principle of sustainable who care about the environment and surrounding communities, will concern human rights, employment, and good governance. 
In addition to the three fundamental aspects, the aspect of climate change become the focus of a specific area.

\section{RESULTS AND DISCUSSION}

\section{Sample}

This research was conducted in companies listed on stock exchanges in their respective countries. But not all companies in Indonesia and Germany has the completeness of the required data. All types of industrial companies listed on the stock market is a sample research unless the company banking and other services. The period of the data used in this study are for 3 years, 2014, 2015 and 2016. The availability of sample data for the study can be seen in table 6 :

Table 6. Sample Selection

\begin{tabular}{lcc}
\hline \multicolumn{1}{c}{ Sample selection } & No of companies & Firm-year \\
\hline Companies listed on Indonesia Stock Exchange and & & \\
Frankfurt Stock Exchange that issue sustainability & & \\
report & 69 & 207 \\
Data isn't in accordance with GRI Guideline & $(12)$ & $(36)$ \\
Data incomplete & $(10)$ & $(30)$ \\
Final Sample & $\mathbf{4 7}$ & $\mathbf{1 4 1}$ \\
\hline
\end{tabular}

In table 6 above is the number of samples used in the study. Initial samples used is a company that published a report on sustainability. But not all companies listed on the stock market the sustainability reports published in accordance with the instructions of GRI. In the period of 3 years of research, there are 69 companies (207 firm-year) that make sustainability report. The data obtained showed a company that makes sustainability report in accordance with GRI as much as 47 companies (141 firm-year).

\section{Descriptive Statistic}

Table 7. Statistic Descriptive

\begin{tabular}{|c|c|c|c|c|c|}
\hline No & Variables & Mean & Std Dev & Min & Max \\
\hline 1 & Em_Disc & 0,59 & 0.29 & 0 & 1,07 \\
\hline 2 & GS (Green Strategy) & 0,53 & 0,27 & 0,06 & 1,02 \\
\hline 3 & SRI & 0,55 & 0,49 & 0 & 1 \\
\hline 4 & Ln_TA & 32,19 & 1,87 & 27,6 & 35,7 \\
\hline 5 & Kd_Ind & 7,5 & 4,7 & 1 & 16 \\
\hline 6 & Kd_Neg & 0,7 & 0,45 & 0 & 1 \\
\hline & $\mathbf{N}$ & 141 & & & \\
\hline
\end{tabular}

Source: Statistic result data 
In table 7, the variable disclosure of carbon emissions showed on average (59\%) of companies disclose information on activities related to emissions. For variable green strategy shows that the average (53\%) of the company strives to increase corporate strategy by increasing the dimensions of the economic, social and environmental. SRI (Socially Responsible Investing) by an average of more than $50 \%$ of the companies do an investment strategy that seeks to consider both financial and social returns.

\section{Hypothesis Testing}

The first hypothesis suggested that green strategy has an impact on disclosure of carbon emissions. The test results indicate that there is a significant positive influence of green strategy and disclosure of carbon emissions. Companies that disclose information whether it's carbon emissions reporting mandatory or voluntary, knowing of the risks and opportunities that may arise in the face of climate change. Companies can integrate the risks and opportunities in corporate strategies that have an impact on the environment. The second hypothesis is guessed that there was an influence of SRI (Socially Responsible Investing) against disclosure of carbon emissions. The results of showed there is a significant positive influence on green investments and disclosure of carbon emissions. Green investment is an investment that is required in adapting to climate change by reducing greenhouse gas emissions without reducing the production and consumption of significantly.

Table 8. Regression Result

\begin{tabular}{|c|c|c|c|c|}
\hline \multicolumn{5}{|c|}{$\begin{array}{l}\text { Model-based regression } \\
\text { EM_DISC }_{\mathrm{it}}=\alpha_{1}+\alpha_{2} \mathrm{GS}_{\mathrm{it}}+\alpha_{2} \mathrm{GI}_{-} \mathrm{SRI} \mathrm{I}_{\mathrm{it}}+\alpha_{3} \mathrm{Size}_{\mathrm{it}}+\alpha_{4} \mathrm{IND} \_S E C k d \_I n d+ \\
\alpha_{5} \mathrm{KD} \text { NEG }+\varepsilon_{\mathrm{it}}\end{array}$} \\
\hline Variable & $\begin{array}{c}\text { Prediksi } \\
\text { Arah }\end{array}$ & Koof & T stat & Sig \\
\hline \multicolumn{5}{|c|}{ Independent variables : } \\
\hline GS & + & 0.834 & 8.55 & $0.000 * * *$ \\
\hline SRI & + & 0.0 .18 & 2.91 & $0.005 * * *$ \\
\hline \multicolumn{5}{|l|}{ Control variables : } \\
\hline Size & + & 0.064 & 1.21 & 0.229 \\
\hline \multicolumn{5}{|l|}{ Industri_sec } \\
\hline \multicolumn{5}{|l|}{ Kd_Neg } \\
\hline $\mathrm{R} 2$ & 0.463 & & & \\
\hline $\mathrm{N}$ & 141 & & & \\
\hline
\end{tabular}

\section{CONCLUSION}

This research generally aims to analyze the influence of the green strategy, green investment, against disclosure of carbon emissions. Global warming leads to extreme climate change in various places around the world including in Indonesia. There is strong evidence that it is caused by human activity, mainly from burning fossil fuels so as to have an impact on the increasing greenhouse gases. One of the company's efforts in reducing the impact of carbon emissions is by disclosure of carbon emissions. The results showed that there was a 
significant influence on green investment strategy and have an impact on the disclosure of the company's carbon emissions.

Implication this study gives evidence of the influence of the green strategy and green investment against disclosure of carbon emissions. However, it should be noted also that each country has different regulations. For example, Indonesia has yet to require issuers to publish sustainability reports, whereas in Europe the company public has been obliged to publish reports on sustainability.

Limitations this study has limitations time span which is used only during the three (3) years, and the sample used is limited to companies in Indonesia and the German, which includes countries that are the biggest producers of carbon emissions in the world. There are still many countries in Europe, USA, China which is the largest emissions-producing country in the world. For the study, expected to be more exploration other factors that have an influence on disclosure of carbon emissions and do a comparison with other countries that do carbon emissions disclosure and use different research methods.

\section{REFERENCES}

Ahmed, K (2014). Environmental Kuznets curve for CO2 emission in Mongolia: an empirical analysis. Management of Environment Quality: An International Journal, 25(4), 505-516

Blackburn, W. R. (2007). The Sustainability Handbook: The complete management guide to achieving social, economics, and environmental responsibility. Earthscan London.

Borghei, Z., Leung, P., \& Guthri, J. (2006). The Nature of voluntary greenhouse gas disclosure-an explanation of the changing rationale: Australian evidence. Mediatory Accounting Research, 24(1), 1-27.

Choi, B. B., Lee, D., \& Psaros, J. (2013). An analysis of Australian company carbon emission disclosure. Pacific Accounting Review, 25(1), 58-79.

Climent, F., \& Soriano, P. (2001). Green and Good? The investment Performance of US Environmental Mutual Funds. Journal of Business Ethics, 103, 275-287.

Czako, V. (2012). Evolution of Hungarian residential energy efficiency support programmes: a road to an operation under the green investment scheme. Energy Efficiency, 5, 163-178.

Deegan, C., \&Soltys, S. (2007). Social accounting research: An Australian perspective. Accounting Forum, 31(1), 73-89.

DiManggio, P.J., \& Powell, W. W. (1983). The Iron Cage Revisited: Institutional Isomorphism and collective rationally in organizational fields. American Sociological Review, 48(2), 147-160.

Donaldson, T., \& Preston, L. E. (1995). The stakeholder theory of the corporation: Concepts, evidence, and implications. Academy of Management Review, 20(1), 85-91

Duarte, S., \& Machado, C. (2013). Modeling lean and green: a review from business models. International Journal of Lean Six Sigma, 4(3), pp 228-250.

Egyedi, T., \& Muto, S. (2010). Standards for ICT-a green strategy in a grey sector. Jaarboek ICT en Samenleving, 7, pp.221-239.

Erygit, N., \& Ozcure, G. (2015). Eco-Innovation as modern era strategy of companies in developing countries: Comparison Between Turkey and European Union. ProcediaSocial a Behaviour Sciences, 195, pp1216-1225.

Eyraud, L., Clements, B., \& Wane, A. (2013). Green Investment: Trends and determinants. Energy Policy, 60, 852-865. 
Freedman, M., \&Jaggi, B. (2005). Global warning, commitment to the Kyoto Protocol, and accounting disclosure by the largest global public firms from polluting industries. The International Journal of Accounting, 40, 215-232.

Ghozali, \& Chairiri. (2007). Teori Akuntansi. Badan Penerbit Undip Semarang.

Ginsberg, J. M., \& Bloom, P. N. (2004). Choosing the right green marketing strategy. MIT Sloan Management Review, 46(1).

Gray, R., Kouhy, R., \& Lavers, S. (1995). Corporate social and environmental reporting. Accounting, Auditing \& Accountability Journal, 8(2), 47-77.

Greenwood, R., \& Suddaby, R. (2006). Institutional Entrepreneurship in Mature Fields: The Big Five Accounting Firms. Academy of Management Journal, 49(1), 27-48.

Guenther, E., Guenther, T., Schiemann, F., \& Weber, G. (2015). Stakeholder Relevance for Reporting: Explanatory Factors of Carbon Disclosure. Business and Society, 1-37.

Hahn, R., Reimsbach, D., \& Schiemann, F. (2015). Organizations, Climate Change, and Transparency: Reviewing the literature on Carbon Disclosure. Organization \& Environment, 28(1), 80-102.

Hansen, E. G., \& Klewitz, J. (2012). The Role of an SME's Green Strategy in Public-Private Eco-innovation Initiatives: The Case of eco profit. Journal of Small Business \& Entrepreneurship, 25(4), pp. 451-478.

IPCC. (2007). Climate Change 2007 Mitigation on Climate Change. Working Group III Contribution to the Fourth Assesment Report of the Intergovernmental Panel on Climate Change UNEP.

Jannah, R., \& Muid, D. (2014). Analisis faktor-faktor yang mempengaruhi Carbon Emission Disclosure pada perusahaan di Indonesia (Studi empiris pada perusahaan yang terdaftar di Bursa Efek Indonesia Periode 2010-2012. Diponegoro Journal of Accounting, 3(2), 1.

Li, K., \& Lin, B. (2006). Heterogeneity analysis of the effects of technological progress on carbon intensity in China. International Journal of Climate Change Strategies and Management, 8(1), 129-152.

Li, Y., Luo, L., \& Tang, Q. (2015). Gender diversity, board independence, environmental committee, and greenhouse gas disclosure. The British Accounting Review, 47, 409424.

Lindrianasari, A., Y. (2014). Comparison of Greenhouse Gas Emission Disclosure Before and after Enactment of the Indonesia Act No.17 of 2004. Social \& Environmental Accounting, 8(4), 224-234.

Luo, L., Lan, Y., C., \& Tang, Q. (2012). Corporate Incentives to Disclose Carbon Information: Evidence from the CDP Global 500 report. Journal of International Financial Management \& Accounting, 23(2), 94-120

Luo, L., \& Tang, Q. (2014a). A Carbon tax, corporate carbon profile and financial return. Pacific Accounting Review, 26(3), 351-373.

Luo, L., \& Tang, Q. (2014b). Does voluntary carbon disclosure reflect underlying carbon performance? Journal of Contemporary Accounting \& Economics, 10, 191-205.

Luo, L., Tang, Q., \& Lan, Y. C. (2013). Comparison of a propensity for carbon disclosure between developing and developed countries A resource constraint perspective. Accounting Research Journal, 26(1), 6-34.

Makower, J. (2009). Strategies for the green economy: opportunities and challenges for the new world of business greenbiz.com.

Matsumura, E. M., Prakash, R., \& Vera-Munoz, S. C. (2014). Firm-Value Effects of Carbon Emission and Carbon Disclosure. The Accounting Review, 89(2), 695-724. 